\title{
ПРОБЛЕМА ПРОФЕСІЙНОГО СПІЛКУВАННЯ ЯК КОМПОНЕНТ МОВНОЇ КУЛЬТУРИ СТУДЕНТІВ ТЕХНІЧНОГО ВИШУ
}

Козак Л. В. Проблема професійного спілкування як компонент мовної культури студентів технічного вишу.

У статті розглядаються проблеми формування професійного спілкування, формування умінь і навичок культури фахового мовлення студентів технічного вишу.

Ключові слова: мова, мовлення, мовна культура, мовна норма, професійне спілкування.

Козак Л. В. Проблема профессионального общения как компонент языковой культуры студентов техического вуза.

В статье рассматриваются проблемы профессионального общения, формирование умений и навычок культуры профессионального общения студентов высших учебных заведений.

Ключевые слова: язык, говорение, языковая культура, языковые нормы, профессиональное общение.

Kozak L. V. Problems of professional communication as students' language culture of higher educational institutions.

Problems of professional communication and formations students' skills of culture and professional communication in higher educational institutions are considered in this article.

Key words: language, talking, language culture, language norms, professional communications.

Постановка проблеми. Культура мови / мовлення - це проблема, що так чи інакше наявна в будь-якому суспільстві й стає предметом обговорення та пильної уваги науковців, письменників та й узагалі людей, небайдужих до виражальних можливостей слова [5, с. 3].

Актуальність дослідження цієї проблеми сьогодні безперечна, бо більшість студентів, та й викладачів технічних навчальних закладів, не завжди дотримуються мовних норм при спілкуванні фаховою мовою. Сьогодні, особливо після прийняття влітку 2012 року Закону про регіональні мови, збільшився вплив російської мови (русизмів та суржику) на якість української мови. Це стосується, 
насамперед, східної частини України, де за 20 років незалежності так $і$ не зникло явище білінгвізму.

Аналіз основних досліджень і публікацій. Проблемі формування культури мови / мовлення студентів, які повинні стати висококваліфікованими фахівцями, присвячено ряд публікацій вітчизняних авторів, зокрема праці Н. Бабич, В. Дубічинського, Е. Огар, Л.Козловської, О. Пономарів та ін. [1, 2, 3, 4, 5].

Мета статті полягає в розв'язанні проблеми професійного спілкування й формуванні мовної / мовленнєвої культури студентів технічного вищого навчального закладу.

Виклад основного матеріалу. Сьогодні проблема мовної культури в професійному спілкуванні розглядається як мовознавцями, так і фахівцями з гірництва, економіки, інформаційних технологій та інших галузей науки й техніки. Це пов'язано з тим, що останні кілька років держава, та й Міністерство освіти і науки, молоді та спорту України, приділяють недостатньо уваги державній мові. Нині ряд вищих закладів освіти самовільно не надають повної кількості годин (54 аудиторні години) на вивчення української мови студентами, Наприклад у нашому виші на гірничому факультету заплановано всього 36 годин (18 лекцій і 18 практичних занять). Це, безумовно, позначається на якості знань студентів, бо деякі важливі теми доводиться подавати у скороченому вигляді.

Мовна культура фахівця - це багатство його словника, досконале володіння способами поєднання слів у речення, уміння розрізняти нейтральні й стилістично марковані мовні одиниці, навички використання професійної термінології тощо.

У процесі навчання не можна обмежуватися тільки накопиченням спеціальних знань. Сьогодні важливіше навчити майбутнього фахівця володіти своїми помислами, спрямувати знання й результати матеріального виробництва на духовне вдосконалення своєї особистості та суспільства.

Формувати мовленнєву та ділову культуру у вищих навчальних закладах повинен комплекс гуманітарних дисциплін, у якому чільне місце посідає «Українська мова (за професійним спрямуванням)». Цей курс у вишах з'явився не так давно замість дещо спрощеного курсу «Ділової української мови» і віддзеркалює принципово новий підхід до розв'язання проблеми гуманітарної освіти студентів технічних та гуманітарних спеціальностей. 
Навчаючи студентів-нефілологів термінології, насамперед треба звертати увагу на проблему професійного спілкування майбутніх фахівців, формування їх мовної культури, дотримання при спілкуванні мовних норм, на місце й роль термінологічної лексики у процесі навчання. У цьому разі при вивченні професійної лексики студентами доцільно також використовувати можливості тезаурусу як ефективного методу описання лексико-семантичних груп термінологічної лексики, що зберігає всі регулярні зв'язки між термінами: і парадигматичні, і синтагматичні.

Використання словників різного типу студентами повинне стати обов'язковим у формуванні мовної культури. При викладанні курсу «Українська мова (за професійним спрямуванням)» особлива увага звертається на такі типи словників, як термінологічні, орфографічні, тлумачні, орфоепічні, словник паронімів та синонімів.

Нерідко при викладанні думок спостерігається незнання фахівцями паронімічних властивостей слова. Часто в реченнях неправильно вживають слова винятково замість виключно, винахідливий замість винахідницький, дослідний замість дослідницький, ефективний замість ефектний, затверджувати замість утверджувати, показник замість покажчик, базисний замість базовий та ряд інших.

Незнання синонімічних можливостей слова часто призводить до помилок у висловленні своїх думок, наприклад: відносно - щодо, йдеться - мова йде, попадати - потрапляти, появлятися з'являтися, притаманний - властивий, протягом - на протязі тощо.

Синонімія $є$ найпоширенішим лексико-семантичним явищем в українській технічній термінології. За загальноприйнятим визначенням під синонімією слід розуміти слова, неминучими семантичними ознаками яких $\epsilon$ лише ті, що можуть стійко нейтралізуватися в певних позиціях. Крім того, синонімами можуть бути термінологічні одиниці різних рівнів.

Для термінознавства важливими ознаками слів-синонімів $є$ їх здатність виконувати в технічному тексті функції заміщення та уточнення. Синонімія тісно пов'язана 3 процесом номінації та $є$ його відображенням. Синонімічні назви можуть бути результатом вторинної номінації якогось поняття. Їхнє існування в мові виправдане лише ii розвитком і є тимчасовим явищем. Причиною виникнення численних синонімічних рядів $\epsilon$ багатогранність

๑ Л. В. Козак, 2012. 
предметів і явищ дійсності та можливість по-різному підійти до цих предметів і явищ у процесі їх пізнання, унаслідок чого у процесі називання тих самих реалій об’єктивного світу виявляються різні ознаки номінації.

Лексична синонімія представлена термінологічними рядами, компоненти яких мають спільну дефініцію й не утворюють переносних значень. Одним зі складників цих рядів є міжнародне або запозичене (скальковане) слово, другим - автохтонне: активатор збудник, депресор - придушувач, інвертор - перетворювач, клема затискач, кокіль - холодильник, міксер - змішувач, иибер - заслінка, шлам - відстій тощо. До цієї групи належать і терміни-епоніми: ефект Юткіна, каскад Кремера, кислота Льюїса, система ВардЛеонарда, система Ільгнера, сталь Альто, струми Фуко та ін.

Синонімія в технічній термінології на рівні варіантності специфічне явище. Проблема мовних варіантів нерозривно пов'язана 3 проблемою норми в мові, яка передбачає обов'язковий вибір одного 3 варіантів.

Лексичне i фразеологічне багатство мовлення твориться синонімічними рядами: чим повніший синонімічний ряд, тим більша можливість відбору відповідно до змісту й мети висловлювання, наприклад: основний, головний, найважливіший, найактуальніший, першочерговий, пріоритетний; міркування, думка, зауваження, переконання, передбачення та ін.

Синонімія термінів у технічних текстах іноді заважає однозначності сприймання, проте варто зазначити, що вона $\epsilon$ свідченням природного розвитку мови. Про це повинні знати студенти для підвищення свого професійного рівня й формування мовної / мовленнєвої культури спілкування.

Семантична структура спеціальної лексики моделюється на матеріалі текстів лекцій, методичних розробок, довідкової та навчальної літератури, наукових журналів. Зміст словникової статті містить такі семантичні зв'язки, як рід - вид, частина - ціле, об'єкт призначення, об'єкт - характеристика. Визначаючи семантичне поле лексичної одиниці, тезаурус встановлює зв'язок між дефініцією та класифікацією. Набір семантичних відношень для тезауруса за допомогою лінгвістичного моделювання типовий для кожного конкретного профілю лексики. 
При підготовці майбутніх фахівців до використання в повсякденній практиці наукової та науково-технічної літератури національною мовою $€$ використання на заняттях 3 української мови спеціальних навчальних текстів, розуміння яких починається 3 оволодіння мовним матеріалом. Синтез цього матеріалу розкривається в правилах граматики і в правилах застосування слів-понять до реальної дійсності.

Проблема функціонування терміна в текстах, зокрема наукових, сьогодні $є$ однією 3 найактуальніших. Якщо художній або публіцистичний текст можна розглядати як проблему естетичну, то науковий текст - як проблему номінаційну. Призначення наукового тексту полягає у викладенні наслідків досліджень про людину, суспільство, явища природи, обгрунтування гіпотез тощо.

Динамічне трактування терміна передбачає пріоритетний розгляд його як текстового явища. Під текстовим характером термінопородження ми розуміємо не стільки його обгрунтованість контекстом, скільки повну залежність цього процесу від потреб самого термінованого тексту.

Динамічне трактування співвідношення терміна й тексту, на наш погляд, зводиться до того, що під текстом розуміється вже не фіксований текст, а сам процес створення тексту.

При аналізі текстів ми будемо враховувати й матеріальну базу термінотворчого процесу, яка формується переважно за рахунок трьох джерел:

1) уже використовуваного термінологічного банку (наприклад, використання в техніці термінів інших наук: функція, поле, інваріант тощо); суть термінотворчого процесу в цьому випадку зводиться до лексичного наповнення відповідної моделі, тому цей вид термінотворення можна визначити як детермінований; за допомогою цього джерела можна створювати складніші термінологічні одиниці, наприклад: електричне поле, азотна кислота та ін.;

2) природної мови (наприклад, сила, тягар, гілка та ін.); друге джерело термінотворення передбачає лише текстовий спосіб породження терміноодиниці, оскільки цей процес завжди пов'язаний iз семантичним переосмисленням слів природної мови;

3) запозичення 3 інших мов (наприклад, атмосфера, електроенергія, комп'ютер, матриця тощо); третє джерело процесу термінотворення розглядається нами як основа процесів творення i відтворення термінологічних одиниць. Тенденція до міжнародної

๑ Л. В. Козак, 2012. 
уніфікації термінології виявляється в тому, що в тесті широко використовуються запозичення.

Сьогодні багато уваги необхідно приділяти виробленню вимог до використання термінів у навчальних та наукових текстах. I наукове, і навчальне видання повинно правильно інтерпретувати відповідну наукову інформацію.

У науковому тексті в доступній для сприйняття формі повинні викладатися найважливіші наукові відомості 3 використанням фахових термінів. Слід враховувати й те, що з науковою інформацією студент повинен не лише ознайомитися, а й засвоїти основні положення, правила, закони та ін. Щодо використання термінів у наукових текстах, то слід дотримуватися таких основних правил їх використання, як основних носіїв наукової інформації:

- необхідно уникати неточно орієнтованих термінів, оскільки вони можуть створювати помилкове уявлення про процес або явище;

- слід уникати багатозначних термінів, а коли це неможливо, давати в тексті необхідні пояснення;

- використовувати, по можливості, коротку форму терміна;

- дотримуватися принципу системності подання термінології певної галузі;

- надавати перевагу власне українським термінам, якщо вони відповідають сучасним мовним нормам і є загальноприйнятими;

- уникати, по можливості, термінів-синонімів;

- використовувати різноманітні прийоми введення й пояснення термінів у тексті.

Аналіз функціонування термінів у наукових текстах довів, що характер його функціонування тісно пов'язаний як зі специфікою самого тексту, так і з лінгвістичною суттю термінології.

Розуміння тексту починається з оволодіння мовним матеріалом i термінологічною лексикою, яка $\epsilon$ своєрідним барометром, що визначає рівень професійної освіти. Сучасна лексикографія зіткнулась 3 трудністю формулювання цих значень у тлумачних словниках.

Найважливішою умовою при вивченні термінографічного матеріалу є системність, яка дозволяє провести паралель між новою й уже відомою інформацією, а також створити умови для такої організації діяльності студентів, при якій певна частина інформації запам’ятовується підсвідомо. 
Іншою важливою умовою при формуванні навичок мовної культури є точність, яка виражається насамперед через термін і за допомогою терміна. Точним можна назвати таке мовлення, коли вжиті слова повністю відповідають їх мовним значенням. Це досягається передусім лексичними ресурсами мови, тобто виявляється на рівні слововживання, але без контексту точності важко досягти. Наприклад, у гірничій термінології не лише студенти, але й викладачі фахових дисциплін плутають такі терміни: вироблення - виробка - виробіток, гірський - гірничий. У Російсько-українському словнику наукової термінології дається таке тлумачення цих термінів:

- вироблення - це дія; виробка - вироблений простір; виробіток - результат роботи;

- гірський - у значенні гірська порода, гірський тиск, гірський перевал; гірничий - це розроблення надр (гірниче підприємство, гірничі роботи, гірнича виробка).

Терміни організовують i впорядковують наукові знання, виконуючи інформативну та пізнавальну функції. Фахівець предметної галузі повинен знати свою поняттєво-термінологічну базу, що відображає галузеві знання. Термінознавство як багатодисциплінарна теоретична наука набуває ознак практичної науки. Тому бажано прилаштувати теоретичні знання термінознавства до потреб повсякденного використання майбутніми інженерами термінології у фаховій діяльності.

У лінгвістиці фахову мову розглядають як тематично обмежену сукупність спеціальних i загальних мовних засобів, що використовуються в певній сфері людської діяльності. Вправне володіння мовою спеціальності передбачає насамперед опанування термінологією свого фаху, уміння використовувати в професійному мовленні ऑï тематичні домінанти, оскільки саме термінологія становить специфіку тієї чи іншої підмови окремих наук.

Фундаментальну частину науково-технічного знання презентують прийняті у відповідній галузі визначення (дефініції) іiі наукових термінів. Визначення термінів значною мірою фіксують відношення між відповідними термінологічними поняттями і власне термінами, відношення, що їх можна розглядати як важливі поняттєві складники змістової структури галузі, до якої належать ці терміни. У лексиці сучасної української літературної мови значне місце посідають наукові видання, зокрема монографії, підручники, навчальні посібники, довідники тощо, які насичені науковою та ๑ Л. В. Козак, 2012. 
технічною термінологією, що поділяється на ряд тематичних груп, які й стали предметом нашого дослідження.

Ми вважаємо, що для розв'язання проблеми професійного спілкування як компонента мовної / мовленнєвої культури студентів, обов'язковим $\epsilon$ встановлення структурно-семантичної специфіки терміносистем, виділення тематичних груп, які повинні вивчати студенти технічного вишу на заняттях не лише з української мови, але й 3 фахових дисциплін.

Під тематичною групою певної терміносистеми розуміємо сукупність галузевих термінів, об'єднаних однією темою за певними семантичними ознаками. Належність лексем до певної тематичної групи визначається методом компонентного аналізу дефініцій термінів за наявністю спільної архісеми (родової семи).

Тематичні групи технічної лексики різні за кількісним складом (від одно- до багатокомпонетних), тобто вони можуть бути як структурно простими, так і складними. У процесі навчання студентів професійного спілкування необхідно починати вивчення цих тематичних груп, зважаючи на:

- позначення назв апаратів, механізмів, пристроїв, приладів та їх частин (акумулятор, акумулятор тиску, амортизатор, анкерний пристрій, апарат, бур, вібратор, вінчестер, втулка, генератор (гідрогенератор), двигун, газотурбінний двигун, ракетний двигун, демпфер, діод (фотодіод), драга, думпкар, запальник, запобіжник, затискач, екскаватор, електростанція, інженерний пульт, інструмент, каркас, компас, компас індукиійний гіроскопічний, комп'ютер, апаратна частина комп'ютера, конвеєр, конвертор, ляда, млин, модулятор, монітор, муфта, навігатор, конвеєр, крекінг, нагрівач, нагромаджувач (блок зберігання інформачії), насос, обігрівач, перфоратор, пірометр, проиесор, регулятор, реактор, респіратор, риштак, сканер, стан (прокатний), стовбур (похилий стовбур), табулятор, таймер, трансформатор, турбіна, цุиклотрон, шабер, шина, шнек тощо);

- терміни, що позначають категорію істот, спільним змістом $\epsilon$ узагальнене словотворче значення «той, хто», тобто тематична група термінів, що називає осіб, професію, рід занять (автокранівник, бетоняр (бетонник), бізнесмен, будівельник, бурильник, вагонник, вагранник (вагранниия), вальцювальник, вулканізаторник, гірник, горновий, диспетчер, доменник, інструментальник 
(інструментальничя), кахельник, кранівник (кранівниця), комп'ютерник, лекальник (лекальничя), ливарник, люковий, маркшейдер, мартенівець, машиніст, металург, механік, моторист, облицювальник, оператор, плавильник, програміст, прохідник, сталевар, тесальник, фарбувальник, футерувальник, шахтар, шихтувальник, иліфувальник, итурман тощо);

- позначення назв процесів та дій (абляція, автометаморфізм, агломерачія, бетонування, вилив (лави), врубування, втискування, гідратація, десульфачія, забруднення, зрошення, комутачія, локальне забруднення, загартування, зварювання, електродугове зварювання, ерозія, комутачія, конструювання, меліорачія, нагрівання, охолоджування, очистка (зачистка), плавлення, синхронізачія, фотосинтез, форматування та ін.);

- позначення назв станів, властивостей предметів та явищ: (агресивна вода, агресивність, важка вода, водостійкість, гідроакустика, гігроскопічність, домінантність, ерозія, компактність, крихкість, розчинність, світлочутливість, теплоємність, термостійкість, утома (металу), щзільність та ін.);

- позначення назв речовин, матеріалів та хімічних елементів (адамант, альбіт, анілін, антрацит, антифриз, базальт, бензин, бензол, бетон, бутан, габро, газ, гас, гас авіачійний, герметик, граніт, залізобетон, ізоляція, калій, каніфоль, керамзит, керамзитобетон, лазурит, метан, нафта, перлітобетон, солідол, стружка, фібробетон, циттрин, илакобетон, илам, иліх тощо);

- позначення назв підприємств, споруд і приміщень спеціального призначення (ангар, завод (металургійний, приладобудівний, машинобудівний), електростанція, лабораторія, машзал, рудник, станція (компресорна станція), цех (інструментальний, прокатний, доменний), шахта тощо);

- позначення величин та одиниць вимірювань (ампер, байт (гігабайт, мегабайт), біт, ват (кіловат), кіловат-година, вебер, вольт, (кіловольт), гери, гільберт, генрі, джоуль, кулон, людиногодина, люмен, моль, ом, паскаль, сантиметр, тонна, фарада, мікрофарада та ін.);

- позначення назв наукових галузей та їх розділів (автоматизація, водна токсикологія, водовідведення, водопостачання, геологія, геодезія, геотермія, гідродинаміка, гірництво, екологія, електростатика, електротермія, електротехніка, інформатика, картографування,

๑ Л. В. Козак, 2012. 
кібернетика, маркшейдерія, металознавство, металургія, метрологія, норми питної води, оптика, програмування, термодинаміка, термометрія фотохімія тощо.

Названими тематичними групами не вичерпується технічна термінологія, але вони є основними, які охоплюють найуживаніші терміни, утворені шляхом запозичення та переосмислення.

На сучасному етапі оформлення технічних термінів в єдину систему відбувається 3 урахуванням найновіших здобутків сфери науки й техніки та під значним впливом мовної інтерференції.

Логічність як ознака мовної культури формується на рівні мислення - мова - мовлення й перебуває в тісному зв'язку з точністю.

Однією 3 визначальних ознак мовної культури фахівця $\epsilon$ правильність мовлення, тобто строга відповідність діючим правилам, за допомогою яких сформульовано норми, які регулюють правильний вибір слова відповідно до змісту та мети висловлювання. Часто при викладанні думок на папері або в усному мовленні студенти допускають стилістичні помилки.

На заняттях 3 курсу «Українська мова (за професійним спрямуванням)» для студентів використовуються цікаві фахові тексти, які розширюють світогляд майбутніх фахівців. У методичних вказівках до виконання практичних робіт 3 теми «Терміни в професійному мовленні» значна увага приділяється етимологічним довідкам, цікавим вправам та завданням, що примушують студентів працювати над усним професійним мовленням.

При вивченні теми «Виразність як ознака культури мовлення» студентам пропонуються такі вправи:

1. Читаючи тексти, навчитися дотримуватися співмірності вдиху й видиху при читанні, на коротких фразах не робити різкого видиху, до кінця довгої фрази не послаблювати сили голосу.

2. Вибрати 3 орфографічного словника слова 3 дублетним наголосом.

3. Виписати 3 орфографічного словника 10 пар слів, у яких наголос виконує смислорозділювальну функцію.

4. Пригадайте правила наголошування складних слів 3 іншомовними постпозиційними компонентами і поставте наголос у таких словах: вольтамперметр, гальванометр, манометр, одноциліндровий (двигун), радіовітромір, субмікроелемент та ін. 
Такі завдання значно пожвавлюють процес засвоєння рідної мови i сприяють формуванню фахової культури мовлення та спілкуванню студентів негуманітарних навчальних закладів.

Чистота мовлення виявляється у трьох аспектах: орфоепії, слововживанні та інтонаційному аспекті. Метою занять $є$ формування стійких навичок літературної вимови, правильного слововживання, вміння розпізнавати позалітературні ненормативні елементи, що засмічують мову. У такому плані побудовані й вправи до вивчення цієї теми:

1. До поданих ненормативних слів та конструкцій (оточуюче середовище, міроприємство, з другого боку, конкурентноспособний, приймати участь та ін.) підберіть нормативні.

2. Підготувати повідомлення на одну із тем рубрики «Правильнонеправильно» (посібник «Антисуржик» за ред. О. Сербенської).

Щодо нелітературного слововживання, то така небезпека для культури мовлення зберігається постійно, бо в мовленні студентів спостерігається часом захоплення жаргонізмами. Засвоєння літературної вимови на сьогоднішній день становить певну трудність для студентів, що не досить часто спілкуються українською мовою. Втрата контролю над власним мовленням призводить до появи слівпаразитів: так би мовити, як би, значить, ну, як кажуть тощо. Урізноманітнюється мовлення й варіюванням сполучників: $i-m a$, алета, щзоб - аби, який - щзо - котрий, хоч - незважаючи на та ін.

Висновки. Отже, рівень розвитку мовної / мовленнєвої культури фахівця відображає рівень розвитку його інтелекту, бо імідж спеціаліста передбачає обов'язкове володіння державною мовою на всіх мовних рівнях: орфоепічному, лексичному, орфографічному, граматичному та стилістичному.

Перспективу подальших розвідок ми вбачаємо у формуванні на заняттях $з$ української мови мовної культури студентів-нефілологів, які повинні не лише оволодіти професійною мовою, але й стати висококваліфікованими фахівцями.

\section{Література}

1. Дубічинський В. Гуманізація технічної освіти / Дубічинський В., Бондар О., Терещенко Л. // Українська термінологія і сучасність : зб. наук. пр. - К. : КНЕУ, 2009. Вип. VIII. - С. $294-298$.

2. Козловська Л. Мовний курс у вищій школі - ефективний інструмент сучасної особистісно-оріснтованої освіти / Л. Козловська // Українська термінологія і

С Л. В. Козак, 2012. 
сучасність : зб. наук. пр. - К. : КНЕУ, 2009. - Вип. VIII. - С. 301 - 304.

3. Культура фахового мовлення : [навч. посіб.] / [за ред. Н. Д. Бабич]. - Чернівці, 2006. -496 c.

4. Огар Е. Термінознавчі дисципліни у навчальному процесі / Е. Огар // Українська термінологія і сучасність : зб. наук. пр. - К. : КНЕУ, 2001. - Вип. IV. - С. 347 - 349.

5. Пономарів О. Культура слова: Мовностилістичні поради : [навч. посіб.] / О. Пономарів. - К. : Либідь, 2001. - 240 с.

6. Російсько-український словник наукової термінології: Математика. Фізика. Техніка. Науки про Землю та Космос / [Гейченко В. В., Завірюхіна В. М., Зеленюк О. О. та ін.]. - К. : Наукова думка, 1998. - 892 с.

Стаття надійшла до редакції 10.12.2012 p. 